\title{
PENERAPAN HAZARD ANALYSIS CRITICAL CONTROL POINT (HACCP) PADA PROSES PENGOLAHAN PRODUK IKAN TUNA BEKU DI UNIT PENGOLAHAN IKANPELABUHAN BENOA - BALI
}

\author{
Nyoman Sutresni ${ }^{1 *)}, M_{a d e}$ Sudiana Mahendra ${ }^{2)}$, I Wayan Redi Aryanta ${ }^{2)}$ \\ ${ }^{1)}$ Dinas Kelautan dan Perikanan Provinsi Bali, \\ ${ }^{2)}$ Program Studi Magister Ilmu Lingkungan Universitas Udayana, \\ ${ }^{*}$ Email: nyoman.sutresni@yahoo.com
}

\begin{abstract}
ABSTRAK
Sistem manajemen mutu dan kemanan pangan yang diterapkan saat ini adalah HACCP (Hazard Analysis Critical Control Point).Faktor penunjang yang menjadi pra-syarat keefektifan penerapan HACCP sebagai sebuah sistem pengendalian mutu adalah terpenuhinya persyaratan kelayakan dasar (GMP dan SSOP).Untuk itu perlu diketahui tingkat penerapan kelayakan dasar (GMP dan SSOP), tingkat penerapan HACCP serta strategi penerapan HACCP.Penelitian ini dilakukan dengan metode cross sectional. untuk mengetahui tingkat penerapan kelayakan dasar (GMP dan SSOP) serta tingkat penerapan HACCP adalah berdasarkan pada jumlah penyimpangan minor, mayor, serius dan kritis.Penentuan strategi penerapan HACCP dengan menggunakan matrik analisis SWOT. Hasil penelitian menunjukkan bahwa tingkat penerapan kelayakan dasar dan tingkat penerapan HACCP pada 15 unit pengolahan ikan yaitu, terdapat 9 unit pengolahan ikan dengan klasifikasi tingkat A (baik sekali) dan 6 unit pengolahan ikan dengan klasifikasi tingkat B (baik).Strategi penerapan HACCP pada proses pengolahan produk ikan tuna beku di unit pengolahan ikan Pelabuhan Benoa-Bali yaitu strategi untuk meningkatkan jaminan mutu dan keamanan pangan serta kualitas lingkungan di lokasi penelitian. Artinya unit pengolahan ikan dilokasi penelitian harus menjaga dan mempertahankan posisi yang berada dalam kondisi yang baik serta melakukan perbaikan-perbaikan internal, baik yang menyangkut bidang produksi, kelembagaan serta pengelolaan lingkungan.Dari hasil penelitian ini dapat disimpulkan bahwa unit pengolahan ikan pada lokasi penelitian di Pelabuhan Benoa telah menerapkan kelayakan dasar (GMP dan SSOP) serta penerapan HACCP dengan baik. Hasil penelitian ini diharapkan dapat dipakai sebagai dasar penelitian lebih lanjut untuk jaminan mutu dan keamanan pangan serta kualitas lingkungan perairan pantai di Pelabuhan Benoa.
\end{abstract}

Kata kunci : Jaminan mutu, keamanan pangan,GMP, SSOP dan HACCP

\section{PENDAHULUAN}

Pengolahan hasil perikanan memegang peranan penting dalam kegiatan pascapanen, sebab ikan merupakan komoditi yang sifatnya mudah rusak dan membusuk, di samping itu usaha pengolahan juga dapat meningkatkan nilai tambah (value added) produk tersebut.Ikan Tuna adalah salah satu andalan ekspor hasil laut Indonesia. Mayoritas ekspor produk ikan tuna Indonesia adalah dalam bentuk beku (Nurjanah, 2011). Produksi ikan tuna walaupun mengalami peningkatan ekspor secara signifikan, produksi ikan tuna masih mendapatkan penolakan negara importir yang berhubungan dengan keamanan pangan. Pada tahun 2013 telah terjadi kasus penolakan produk perikanan Indonesia di negara mitra yaitu: Italia sebanyak 1 kasus, Jerman 2 (dua) kasus, Perancis 1 (satu) kasus, Spanyol 1 (satu) kasus, Korea 3 (tiga) kasus, Rusia 4 (empat) kasus dan Kanada 3 (tiga) kasus. Dari kasus-kasus tersebut yang menjadi alasan penolakan adalah kandungan Methyl mercury, Escherichia coli, Listeria, Heavy metals, Histamin dan sensory (decomposed) (BKIPM, 2014).Dalam mewujudkan jaminan mutu dan keamanan pangan, maka sistem manajemen mutu dan kemanan pangan yang diterapkan saat ini adalah HACCP(Hazard Analysis Critical Control Point) yaitu suatu sistem jaminan mutu yang berdasarkan pada kesadaran atau penghayatan bahwa bahaya dapat timbul di berbagai titik atau tahap produksi tertentu, tetapi dapat dilakukan pengendalian untuk mengontrol bahayabahaya tersebut (Kementerian Kelautan dan Perikanan, 2010). Menurut Wiryanti dan Witjaksono (2001), HACCP sebagai suatu sistem pengendalian mutu tidak dapat berdiri sendiri, tetapi harus ditunjang oleh faktor-faktor lain yang menjadi dasar dalam menganalisis besar kecilnya resiko terjadinya bahaya. Faktor penunjang yang menjadi pra-syarat keefektifan penerapan HACCP sebagai sebuah sistem pengendalian mutu adalah terpenuhinya persyaratan kelayakan dasarunit pengolahan yang meliputi; a) Cara berproduksi yang baik dan benar (Good Manufacturing Practices/GMP), b)Standar prosedur operasi sanitasi (Sanitation Standard Operating Procedure/SSOP). Sehinggga perlu untuk 
diketahui tingkat penerapan kelayakan dasar (GMP dan SSOP), tingkat penerapan HACCP serta strategi penerapan HACCP pada proses pengolahan produk ikan tuna beku di unit pengolahan ikan yang ada di Pelabuhan Benoa. Dengan menerapkan sistem jaminan mutu dan keamanan pangan melalui penerapan HACCP, masyarakat dunia akan semakin yakin terhadap produk perikanan Indonesia.

\section{METODOLOGI}

Penelitian ini dilakukan dengan metode cross sectional. Sedangkan pendekatan yang diterapkan dalam penelitian ini adalah pendekatan kualitatif. Metode dan Teknik pengumpulan data yang digunakan dalam penelitian ini adalah dengan triangulasi teknik, berarti peneliti menggunakan teknik pengumpulan data yang berbeda-beda untuk mendapatkan data dari sumber yang sama, seperti observasi partisipatif, wawancara mendalam dan dokumentasi untuk sumber data yang sama secara serempak.Tujuan dari triangulasi bukan untuk mencari kebenaran tentang beberapa fenomena tetapi lebih pada peningkatan pemahaman peneliti terhadap apa yang telah ditemukan (Sugiyono, 2010). Penelitian ini dilakukan selama 5 (lima) bulan, yaitu pada bulan Januari 2015 sampai dengan Mei 2015.

Penilaian penerapan kelayakan dasar dan penerapan HACCP pada 15 unit pengolahan ikan dengan produk akhir ikan tuna beku di lokasi penelitian dilakukan dengan menggunakan checklist yang berdasarkan pada penyimpangan (deficiency).Untuk menentukan tingkat penerapan kelayakan dasar dan tingkat penerapan HACCP berdasarkan penyimpangan (deficiency) yang ada pada 15 unit pengolahan ikan dengan produk akhir ikan tuna beku di lokasi penelitian mengacu pada peraturan Kepala Badan Karantina Ikan, Pengendalian Mutu dan Keamanan Hasil Perikanan selaku Otoritas Kompeten Nomor : PER.03/BKIPM/ 2011 tentang Pedoman Teknis Penerapan Sistem Jaminan Mutu dan Keamanan Hasil Perikanan (BKIPM, 2011) bahwa penerapan HACCP dapat diklasifikasikan sebagai berikut :

1. Tingkat A (Baik Sekali) : Temuan ketidaksesuaian adalah kritis $(\mathrm{kr})=0$, serius $=$ 0 , mayor $(\mathrm{my})=$ maksimal 5 dan $\operatorname{minor}(\mathrm{mn})=$ maksimal 6.

2. Tingkat B (Baik) : Temuan ketidaksesuaian adalah kritis $(\mathrm{kr})=0$, serius $=$ maksimal 2 , mayor $(\mathrm{my})=$ maksimal 10 dan minor $(\mathrm{mn})=$ maksimal 7 (Jumlah mayor dan serius tidak lebih dari 10).

3. Tingkat C (cukup) : Temuan ketidaksesuaian adalah kritis $(\mathrm{kr})=0$, serius $=$ maksimal 4 , mayor $(\mathrm{my})=$ maksimal 11 dan minor $(\mathrm{mn}) \mathrm{e} " 7$.
Metode dan teknik analisis data dalam penentuan strategi penerapan HACCP yaitu dengan menggunakan matrik analisis SWOT.

Menurut Rangkuti (2006), analisis SWOT membandingkan antara faktor-faktor eksternal yang merupakan peluang (opportunity) dan ancaman (threath) dengan faktor-faktor internal yang merupakan kekuatan (strength) dan kelemahan (weakness).

\section{HASIL DAN PEMBAHASAN}

Dari 15 unit pengolahan ikan di Pelabuhan Benoa yang menjadi sampel didapatkan hasil bahwa sebanyak 9 unit pengolahan ikan yang penerapan kelayakan dasar (GMP,SSOP) serta HACCP dengan klasifikasi tingkat A (baik sekali) dan 6 unit pengolahan ikan dengan klasifikasi tingkat B (baik) dengan penyimpangan minor, mayor dan serius yang didominasi oleh;Kurangnya kesadaran personil terhadap pencegahan kontaminasi silang dan kurang maksimalnya pengawasan petugas terhadap sarana dan prasarana yang digunakan selama proses produksi, Kementerian Kelautan dan Perikanan (2013), menyatakan bahwa persyaratan pekerja yang menangani langsung proses penanganan dan pengolahan hasil perikanan adalah menggunakan pakaian kerja yang bersih, masker dan tutup kepala sehingga dapat menutupi hidung dan rambut secara sempurna demikian pula dengan peralatan dan perlengkapan yang digunakan berhubungan langsung dengan ikan yang diolah harus dirancang dan dibuat dari bahan tahan karat, tidak beracun, tidak menyerap air, mudah dibersihkan dan tidak menyebabkan kontaminasi.Kurang maksimalnya pengawasan petugas terhadappenyimpanan produk jadi di cold storage, Badan Standardisasi Nasional (2006), menyatakan bahwa penataan produk dalam gudang beku diatur sedemikian rupa sehingga memungkinkan sirkulasi udara dingin dapat merata dan memudahkan pembongkaran. Kurang maksimalnya pemantauan terhadap limbah cair yang dihasilkan, menurut Peraturan Gubernur Bali Nomor 8 Tahun 2007 Pasal 5 ayat 3 (Pemerintah Provinsi Bali, 2007), bahwa penanggung jawab usaha yang membuang limbah ke lingkungan mempunyai kewajiban : (a) melakukan pengelolaan limbah sebelum dibuang ke lingkungan sehingga tidak melampaui baku mutu lingkungan hidup, (b) mencegah terjadinya pencemaran dan/atau kerusakan lingkungan dan (c) menyampaikan laporan hasil pemantauan paling lama 6 (enam) bulan sekali kepada Gubernur dan instansi teknis yang membidangi kegiatan yang bersangkutan.Kurang maksimalnya program monitoring air internal yang dilakukan, BKIPM (2013), menyatakan bahwa 
frekuensi monitoring pengujian air dan es yang dilakukan oleh unit pengolahan ikan (dalam rangka own check) harus sesuai kriteria yaitu frekuensi pengambilan dan pengujian sampel untuk monitoring air secara internal (own check) dilakukan terhadap masing-masing kran (outlet) dengan minimal frekuensi 1 (satu) kali dalam 3 (tiga) bulan untuk parameter mikroba dan 1(satu) kali dalam 1 (satu) tahun untuk parameter kimia wajib. Belum lengkapnya identifikasi bahaya yang tercantum dalam analisis bahaya pada manual HACCP, menurut Cato (1998), menyatakan bahwa faktor utama yang menentukan apakah bahaya adalah signifikan untuk tujuan HACCP adalah kemungkinan terjadinya suatu penyakit yang merugikan dan tingkat keparahan, bahaya yang memiliki tingkat keparahan yang tinggi seperti kematian dari adanya bakteri Clostridium botulinum, demikian pulamenurut Afoakwa, et al. (2013), bahwa analisis bahaya dilakukan dengan melakukan tiga tahap kegiatan yang terdiri dari; menyusun daftar semua potensi bahaya (fisik, kimia dan mikrobiologi) yang mungkin terjadi selama pemrosesan, mengevaluasi potensi bahaya berdasarkan tingkat keparahan dan kemungkinan terjadinya bahaya dan terakhir menunjuk langkahlangkah pencegahan atau kontrol diterapkan untuk setiap bahaya.Tingkat penerapan kelayakan dasar pada proses pengolahan ikan tuna beku di lokasi penelitian dapat dilihat pada Tabel 1 dan untuk tingkat penerapan HACCP disajikan pada tabel 2.

Untuk melihat posisi tingkat penerapan kelayakan dasar dan tingkat penerapan HACCP pada masing-masing unit pengolahan ikan di lokasi

Tabel 1.Tingkat Penerapan Kelayakan Dasar pada proses pengolahan ikan tuna beku di unit pengolahan ikan Pelabuhan Benoa-Bali

\begin{tabular}{|c|c|c|c|c|c|c|}
\hline \multirow{2}{*}{ No. } & \multirow{2}{*}{ Lokasi Penelitian } & \multicolumn{4}{|c|}{ Jumlah Penyimpangan } & \multirow{2}{*}{ Tingkat Fasilitas } \\
\hline & & Minor & Mayor & Serius & Kritis & \\
\hline 1. & L1 & 0 & 4 & 1 & 0 & B (Baik) \\
\hline 2. & L2 & 1 & 4 & 1 & 0 & B (Baik) \\
\hline 3. & L3 & 0 & 3 & 0 & 0 & A (Baik Sekali) \\
\hline 4. & L4 & 1 & 4 & 1 & 0 & $B$ (Baik) \\
\hline 5. & L5 & 0 & 3 & 0 & 0 & A (Baik Sekali) \\
\hline 6. & L6 & 1 & 6 & 1 & 0 & $B$ (Baik) \\
\hline 7. & L7 & 1 & 3 & 0 & 0 & A (Baik Sekali) \\
\hline 8. & L8 & 1 & 4 & 1 & 0 & B (Baik) \\
\hline 9. & L9 & 0 & 3 & 0 & 0 & A (Baik Sekali) \\
\hline 10. & L10 & 1 & 3 & 0 & 0 & A (Baik Sekali) \\
\hline 11. & L11 & 1 & 6 & 1 & 0 & $B$ (Baik) \\
\hline 12. & L12 & 0 & 3 & 0 & 0 & A (Baik Sekali) \\
\hline 13. & L13 & 0 & 3 & 0 & 0 & A (Baik Sekali) \\
\hline 14. & L14 & 1 & 3 & 0 & 0 & A (Baik Sekali) \\
\hline 15. & L15 & 1 & 3 & 0 & 0 & A (Baik Sekali) \\
\hline
\end{tabular}

Tabel 2.Tingkat Penerapan HACCP pada proses pengolahan ikan tuna beku di unit pengolahan ikan Pelabuhan Benoa-Bali

\begin{tabular}{|c|c|c|c|c|c|c|}
\hline \multirow{2}{*}{ No. } & \multirow{2}{*}{ Lokasi Penelitian } & \multicolumn{4}{|c|}{ Jumlah Penyimpangan } & \multirow{2}{*}{ Tingkat Fasilitas } \\
\hline & & Minor & Mayor & Serius & Kritis & \\
\hline 1. & L1 & 0 & 6 & 1 & 0 & B (Baik) \\
\hline 2. & 12 & 1 & 6 & 1 & 0 & $B$ (Baik) \\
\hline 3. & L3 & 0 & 5 & 0 & 0 & A (Baik Sekali) \\
\hline 4. & L4 & 1 & 6 & 1 & 0 & $B$ (Baik) \\
\hline 5. & L5 & 0 & 4 & 0 & 0 & A (Baik Sekali) \\
\hline 6. & L6 & 1 & 8 & 1 & 0 & $B$ (Baik) \\
\hline 7. & L7 & 1 & 4 & 0 & 0 & A (Baik Sekali) \\
\hline 8. & L8 & 1 & 6 & 1 & 0 & B (Baik) \\
\hline 9. & L9 & 0 & 4 & 0 & 0 & A (Baik Sekali) \\
\hline 10. & L10 & 1 & 4 & 0 & 0 & A (Baik Sekali) \\
\hline 11. & $\mathrm{~L} 11$ & 1 & 8 & 1 & 0 & B (Baik) \\
\hline 12. & L12 & 0 & 5 & 0 & 0 & A (Baik Sekali) \\
\hline 13. & L13 & 0 & 4 & 0 & 0 & A (Baik Sekali) \\
\hline 14. & L14 & 1 & 5 & 0 & 0 & A (Baik Sekali) \\
\hline 15. & L15 & 1 & 5 & 0 & 0 & A (Baik Sekali) \\
\hline
\end{tabular}




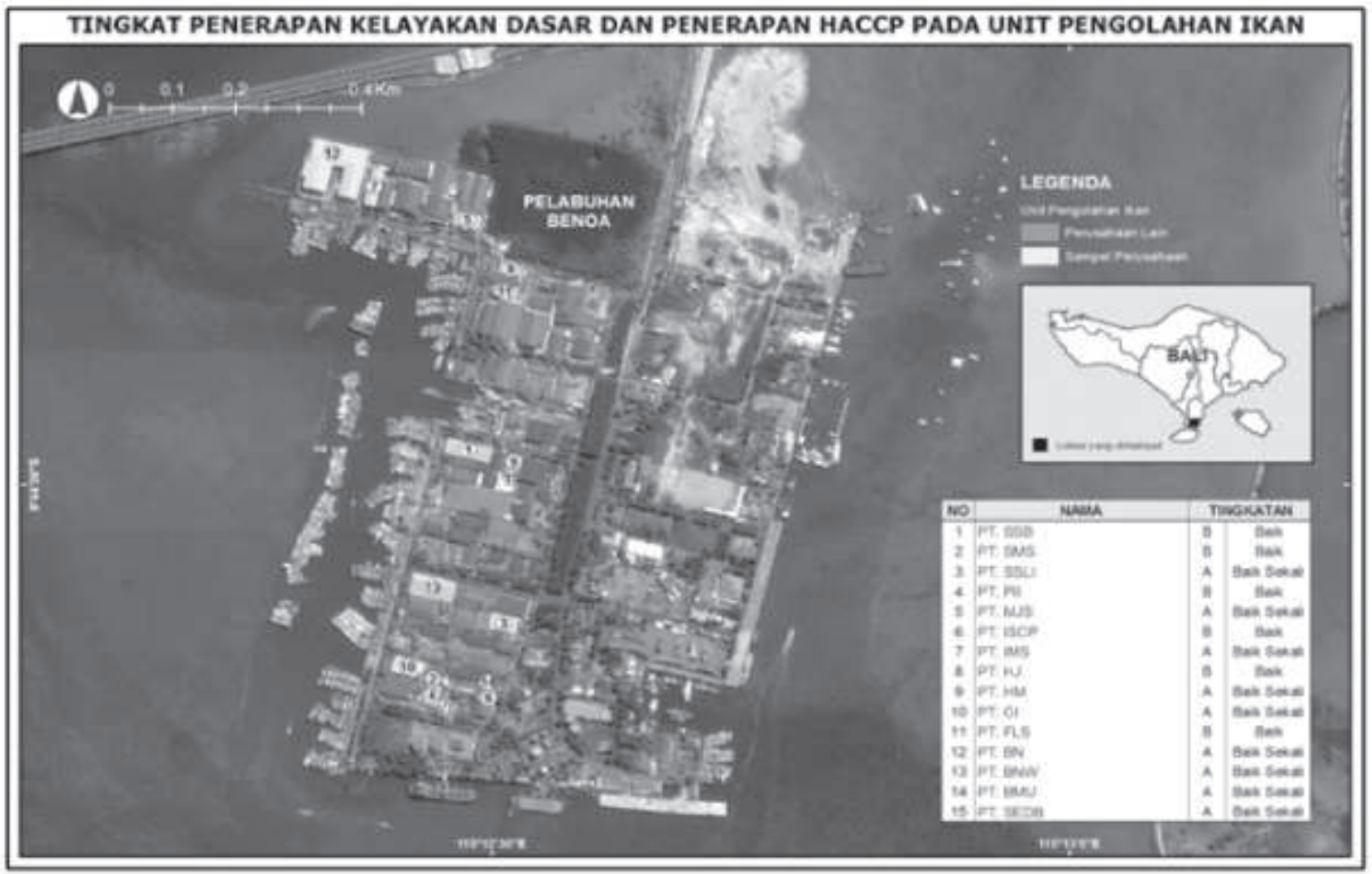

Gambar 1. Tingkat penerapan kelayakan dasar dan tingkat penerapan HACCP pada unit pengolahan ikan di lokasi penelitian Pebuhan Benoa-Bali

penelitian Pelabuhan Benoa-Bali dapat di gambarkan dalam sebuah peta sebaran yang disajikan pada Gambar 1.

Berdasarkan matrik analisis SWOT, dimana faktor internal yang berupa kekuatan (strengths) dan kelemahan(weaknesses)serta faktor eksternal yang berupa peluang (opportunities)dan ancaman (threath), maka didapatkan strategi untuk meningkatkan jaminan mutu dan keamanan pangan serta kualitas lingkungan di lokasi penelitian antara lain :

1. Penyesuaian ruang lingkup serta frekuensi pengujian air pada proses produksi untuk lokasi penelitian L1, L2, L4, L6, L8 dan L11.

2. Peningkatan kapasitas pelatihan serta jaminan kesehatan bagi karyawan bagian produksi untuk lebih meningkatkan kesadarannya terhadap pencegahan kontaminasi silangdi unit pengolahan ikan pada semua lokasi penelitian.

3. Pelaksanaan pemantauan terhadap limbah cair yang dihasilkan sesuai Peraturan Gubernur Bali No. 8 Tahun 2007 pada lokasi L3, L5, L7, L9, L10, L12, L13, L14 dan L15.

4. Pembuatan sistem pengolahan limbah cair sebelum dibuang ke perairan umum untuk L1, L2, L4, L6, L8 dan L11.

5. Peningkatan ketelitian dalam menganalisis bahaya, yaitu dalam menganalisis potensi bahaya mempertimbangkan kemungkinan penyebab terjadinya bahaya, tingkat keparahan yang mempengaruhi konsumen, ketahanan ketika terkena bahaya, perhatian terhadap mikroba yang dapat berkembangbiak dan bertahan hidup pada produk, adanya racun, bahan kimia atau benda asing. Risiko keamanan pangan yang harus diperiksa meliputi aspek keamanan kontaminasi bahan kimia, aspek keamanan kontaminasi fisik dan aspek keamanan kontaminasi biologis termasuk di dalamnya mikroba.

6. Peningkatan efektivitas pelaksanaan prosedur verifikasi pada L1, L2, L4, L6, L8 dan L11.

\section{SIMPULAN DAN SARAN}

\subsection{Simpulan}

Berdasarkan hasil penelitian dan pembahasan dapat ditarik beberapa kesimpulan sebagai berikut:

1. Tingkat penerapan kelayakan dasar (GMP, SSOP) pada proses pengolahan produk ikan tuna beku di 15 unit pengolahan ikan Pelabuhan Benoa- Bali,terdapat 9 (Sembilan) unit pengolahan ikan yang tingkat penerapan kelayakan dasar (GMP dan SSOP) dengan klasifikasi tingkat A (baik sekali) dan6 (enam) unit pengolahan ikan dengan klasifikasi tingkat B (baik), karena pada 6 unit pengolahan ikan ini masih terdapat satu buah temuan serius, yaitu limbah cair belum ditangani secara higinis dan 
ramah lingkungan,untuk itu perlu melakukan pengelolaan limbah cair sebelum dibuang ke lingkungan sehingga tidak melampaui baku mutu lingkungan hidup.

2. Tingkat penerapan HACCP pada proses pengolahan produk ikan tuna beku di 15 unit pengolahan ikan Pelabuhan Benoa- Bali,terdapat 9 (Sembilan) unit pengolahan ikan yang tingkat penerapan HACCP dengan klasifikasi tingkat A (baik sekali)dan6 (enam) unit pengolahan ikan dengan klasifikasi tingkat B (baik), karena pada 6 unit pengolahan ikan ini masih terdapat satu buah temuan serius, yaitu belum pernah melakukan pemantauan terhadap limbah cair yang dihasilkan sebelum dibuang ke lingkungan, sehingga perlu melakukan pengujian terhadap limbah cair yang dihasilkan sebelum dibuang ke lingkungan.

3. Strategi penerapan HACCP pada proses pengolahan produk ikan tuna beku di unit pengolahan ikan Pelabuhan Benoa-Bali yaitu strategi untuk meningkatkan jaminan mutu dan keamanan pangan serta kualitas lingkungan di lokasi penelitian. Artinya unit pengolahan ikan dilokasi penelitian harus menjaga dan mempertahankan posisi yang berada dalam kondisi yang baik serta melakukan perbaikanperbaikan internal, baik yang menyangkut bidang produksi, kelembagaan serta pengelolaan lingkungan demi tercapainya kapabilitas yang tinggi serta menunjang kelancaran ekspor hasil perikanan bagi unit pengolahan ikan yang ada di lokasi penelitian Pelabuhan Benoa.

\subsection{Saran}

1. Disarankan kepada pihak unit pengolahan ikanuntuk melakukan peningkatan kapasitas pelatihan karyawan dan memperketat pengawasan terhadap sarana yang terkait dengan kegiatan proses produksi.

2. Dalam upaya pengelolaan lingkungan, perlu adanya kerjasama antara PT. Persero Pelindo III selaku pengelola pelabuhan Benoa dengan pengusaha (pihak unit pengolahan ikan) yang ada di Pelabuhan Benoa untuk mengusahakan sistem pengelolaan air limbah yang lebih efektif, misalnya dengan sistem sanimas (Sanitasi Masal).

3. Perlu dilakukan penelitian mengenai kualitas perairan pantai di kawasan pelabuhan Benoa untuk peneliti selanjutnya.

\section{DAFTAR PUSTAKA}

Afoakwa, E.O., Mensah-Brown, H., Budu, A.S. and Mensah, E. 2013. Risk Assessment of VacuumPacked Pouched Tuna Chunks During Industrial Processing Using ISO 22.000 and HACCP Systems. International Food Research Journal 20 (6) : 3357-3371.

Badan Standardisasi Nasional. 2006.Tuna Steak Beku - Bagian 3: Penanganan dan Pengolahan,SNI 01-4485.3-2006. BSN: Jakarta.

BKIPM. 2011. Peraturan Kepala Badan Karantina Ikan, Pengendalian Mutu dan Keamanan Hasil Perikanan Nomor : PER. 03/BKIPM/2011 Tentang Pedoman Teknis Penerapan Sistem Jaminan Mutu dan Keamanan Hasil Perikanan. KKP : Jakarta.

BKIPM. 2013. Petunjuk Teknis Persyaratan Air dan Es untuk Penanganan dan Pengolahan Hasil Perikanan. KKP: Jakarta.

BKIPM. 2014. Perkembangan Data Kasus Penolakan Ekspor Produk Perikanan Indonesia. KKP: Jakarta.

Cato, J.C. 1998. Seafood Safety; Economics of HACCP Proggrammes, Fish Utilization and Marketing Service, Fishery Industries Division, FAO Fisheries Departement, Rome, Italy.

Kementerian Kelautan dan Perikanan. 2010. Peraturan Menteri Kelautan dan Perikanan Nomor PER.19/MEN/2010 Tentang Pengendalian Sistem Jaminan Mutu dan Keamanan Hasil Perikanan. KKP: Jakarta.

Kementerian Kelautan dan Perikanan. 2013. Keputusan Menteri Kelautan dan Perikanan Nomor 52 A/KEPMEN-KP/2013 Tentang Persyaratan Jaminan Mutu dan Keamanan Hasil Perikanan pada Proses Produksi, Pengolahan dan Distribusi. KKP: Jakarta.

Nurjanah. 2011. Pengetahuan dan Karakteristik Bahan Baku Hasil Perairan. IPB Press: Bogor.

Pemerintah Provinsi Bali. 2007. Peraturan Gubernur Bali Nomor 8 Tahun 2007 Tentang Baku Mutu Lingkungan Hidup dan Kriteria Baku Kerusakan Lingkungan Hidup.

Rangkuti. 2006. Analisis SWOT Teknik Membedah Kasus Bisnis. PT. Gramedia Pustaka Utama: Jakarta.

Sugiyono. 2010. Metode Penelitian Kuantitatif dan Kualitatif dan $R \& D$. Alfabeta : Bandung.

Wiryanti, J dan H. T. Witjaksono. 2001. Konsepsi $H A C C P$. Jakarta. 